\title{
Global Economic Shock Spillovers to the Saudi Economy: An Assessment Framework
}

\author{
Hend M. Alsheikh \\ Financial and Economic Sector \\ Institute of Public Administration, Riyadh, Saudi Arabia \\ sheikhhi@ipa.edu.sa \\ On a secondment with King Abdullah University of Science and \\ Technology Policy \& Strategy Consultant \\ Hend.Alsheikh@kaust.edu.sa
}

(Submitted October 2011, accepted June 2012)

\begin{abstract}
This paper introduces a framework for assessing global shock spillover specifically address the global financial spillovers to the Saudi economy by exploring the main fundamental determinants of creditworthiness including key global factors, Macroeconomic and Financial Sector vulnerability. Finally highlights the extent to which the Saudi financial system have been able to regain a sound standing in the aftermath of the recent financial crises to which they have been subjected. The main conclusion is that global financial crisis has had limited direct impact so far on domestic financial markets but, the country was and still effected through trade, reflected in high inflation rate, tighter liquidity and weak investor confidence. Government generous spending has been successful in reducing the impact of the global crisis, but Saudi Arabia should adopt alternative venue to the current high spending levels. In light of anticipated fall in oil prices, the current strategy is not sustainable.
\end{abstract}

Keywords: financial vulnerability, shock spillovers, Saudi economy.

GEL Classification: G01, G12, G14 


\section{Introduction}

There is substantial body of literature indicating that emerging markets creditworthiness cushions their economies from global financial turbulence. The main fundamental determinants of creditworthiness mainly: Macroeconomic (inflation rate, term of trade, exchange rate system), liquidity -solvency indicators, and key global factors include U.S interest rate, oil prices and equity prices (Martin, Bannister, Gelos and Valencia) were found to be determinant of shocks spillovers. Empirical evidence were presented in many studies showing that financial shock transmission during crises depends on financial and trade linkages (Dooley, Fernandes and Klezer 1994, Eichengreen and Ashoka 1998, Arora and Cerisola 2000, Gapen and others 2005). There are also a consensus among experts that strong local banking system and securities markets reduces a country's external vulnerability through enhanced collection and better allocation of domestic savings in good times (Martin, Bannister, Gelos and Valencia).

Saudi Arabia, as well as the rest of the GCC countries, experienced robust growth for the past 6 years in the wake of high oil prices from 20032008. Growth has picked up from 0.1 percent in 2002 to 7.1 percent in 2003, averaging about 5.1\% from 2003-2007. The Saudi current account has posted surpluses of $24.3 \%$ of GDP for that period. Accumulating annually on average some US\$ 285bn in Foreign Exchange. However, such performance was overshadowed by the recent sever global economic slow down and the extreme volatility in oil prices. Recent global economic crisis has revealed important flaws in the current global architecture and raised concerns about the solidness of these surplus economies and the efficiency of their financial and monetary policies. An optimist would highlight that the governments of the region ability to cushion their economies from the credit and demand crunch. A pessimist however would stress the thinness of the capital market, the fragmented nature of local markets and regulatory obstacles. I would argue that the situation lies somewhere between the two. The assets of the financial institutions are highly dependent on the domestic financial environment and on global market conditions. The experiences of other countries proved that the soundness of a country's financial system and the regulatory framework within which it operates are partly shaped by the adverse shocks that the system endures over time and by the regulator's response to such shocks (Martin, Bannister, Gelos and Valencia). 
This paper introduces a framework for assessing global shock spillover specifically address the global financial spillovers to the Saudi economy by exploring the main fundamental determinants of creditworthiness including key global factors, Macroeconomic and Financial Sector vulnerability. Finally highlights the extent to which the Saudi financial system have been able to regain a sound standing in the aftermath of the recent financial crises to which they have been subjected.

\section{Literature review}

Economic theory is ambiguous about the cross-country growth/recession spillover, but recent research provides evidence to a positive relationship as far as financial linkages are concerned (Ilahi and Shendy). IMF (WEO 2008) examined in detail spillovers from the US into Asia and found that negative aggregate demand shocks in the US induce economic slowdown in Asia, and these tend to be much stronger when global confidence is affected. In country specific studies, Kanda (2008) analyzed shocks spill from key trading partners (U.S., Euro area and the U.K.) over on Ireland growth as well as to gauge the effect on growth of a steady loss in competitiveness and founds that shocks to U.S. growth have a significant impact on Irish economic performance: a point of reduction in U.S. growth leads to a 1.8 percent decline in Irish GDP. Klyuev (2008) investigated empirically the impact of changes in U.S. financial conditions on financial conditions and real economic activity in Canada. He found that changes in U.S. financial conditions have significant implications for real activity in Canada. The estimated impact can be decomposed into three channels; 1- A direct financial channel, where the slowdown is attributed to a rising cost of funds for Canadian companies raising capital in the United States. 2- An indirect financial channel, where growth is hampered as financial conditions in Canada tighten in response to a tightening in the United States. 3- And the trade channel, which operates through a slowing in the U.S. economy and leads to lower demand for Canadian exports. The direct financial channel dominates in the short run. Bayoumi and Swinston (2007A) found that U.S. and global shocks generate significant spillovers to other regions of about $1 / 3$ to $1 / 2$ of the size of the initial shock after 2 years. Spillovers from the Euro area and Japan, on the other hand, tend to be insignificant. The authors also use the proposed identification technique to identify the major channels through which shocks are propagated among the major economies. 
Financial variables are found to play the largest role in the transmission of global and U.S. In another paper by Bayoumi and Swinston (2007B) they focused on the underlying sources of cross-border linkages among international bond markets. In addition, they found strong evidence of U.S. real and nominal yields spillovers into other countries (except for Austria and Japan), but limited reverse causation. Evidence on inflation expectations, however, suggests that spillovers are weaker but two-ways. While, on average, U.S. factors may determine at least one-half of foreign real interest rates, U.S. inflation expectations account for a quarter to a third of fluctuations in foreign inflation expectations, implying that expectations are largely driven by domestic events. ChanLau, Mitra, and Ong (2007) identified potential cross border risk concentrations among the world's systemically important banks. They found evidence of home bias effects and that not all banks tend to be similarly affected by common shocks to the global economy or financial system. They also found that bank soundness is more susceptible to common (macro and market) shocks when the global environment is turbulent. In estimating Spill over risk among large EU banks Čihák and Ong (2007) found that there exist a conditional probability of a bank being in distress if another bank is already in distress and they argue for strong cross-border supervisory cooperation in the region justified by several events with significant cross-border spillover effects. Duggar and Mitra's (2007) found significant cross-border contagion risk from the U.K., the U.S. and the Netherlands to the Irish banks. The Impact of U.S growth on other counties was examined by Arora and Vamvakidis (2004), and they found a significant positive impact of U.S growth on the growth of the rest of the world especially developing countries (the impact was one for one in some specific countries). The implication of this study for the Saudi economy is clear because the U.S is a major trading partner - Saudi Arabia remained the largest U.S. trading partner in the Middle East in 2010. According to the U.S. International Trade Administration, Saudi exports to the United States were $\$ 31.4$ billion up from $\$ 22$ billion in 2009 but below the 2008 figure of $\$ 54.8$ billion. And U.S. exports to Saudi Arabia are estimated at $\$ 11.6$ billion up from $\$ 10.8$ billion in 2009. But below the 2008 figure of $\$ 12.5$ billion- and a growth or slow down in their economy effects the Saudi economy in the same direction. The World Economic and Financial Surveys, REO (2008) briefly illustrates the impact of the sub prime crisis on Latin America's financial sector. The study links the 2007 sub prime crisis to a widening 
of external credit spreads, a pausing of overseas corporate financing, and a retreat in stock markets.

The literature has singled out that U.S markets have a profound effect on the rest of the world, and are considered the main driver of global markets. The question of how spillovers changed over time was addressed extensively in the literature and most studies found out that with growing financial integration spillovers have been stronger- as the recent global shock revealed. A bulk of the literature examined the effect of foreign interest rate shocks on emerging market under fixed and floating exchange rate regime finding a rapid and strong transmission in pegged exchange rate regimes-with estimates of interest rate passthrough sometimes exceeding 1. Regarding policy implications for emerging markets -such as the Saudi market- the literature highlighted the role of fundamentals such as openness of the economy- more open economies seem less vulnerable to sudden stops, also, financial buffers such as high reserves help protect countries from contagion, as expected to witness in oil rich countries.

\section{Key Global Factors May Trigger Crises}

- Global Economic Turbulence

- Decline in Commodity prices (Oil)

- Direct/indirect exposure to global Crisis

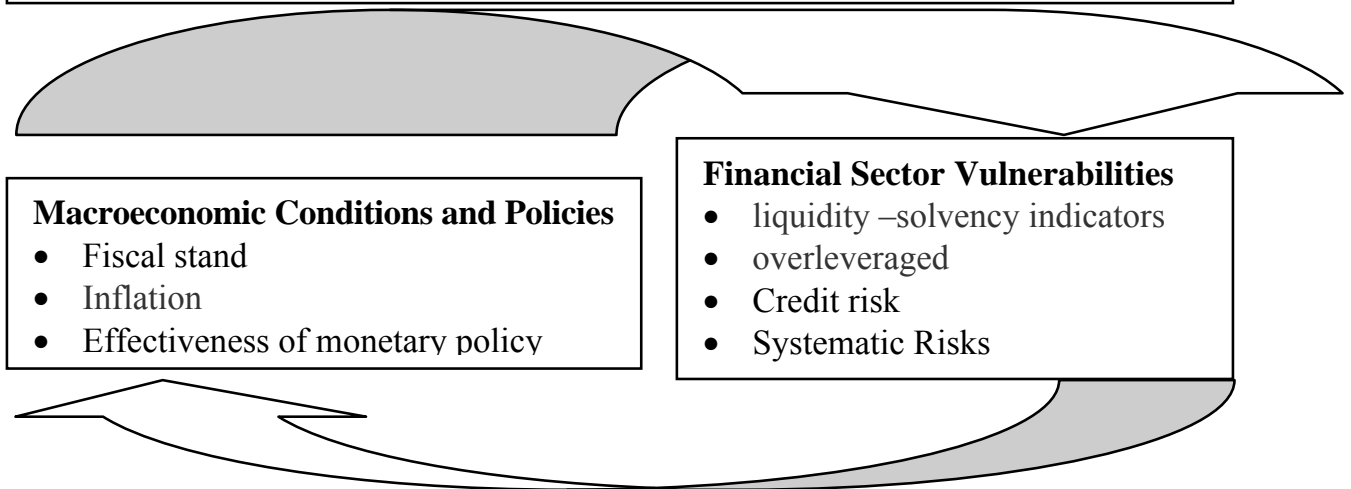

- Financial Soundance and Macroeconomic Maturity Determine the scope of the spillovers and the appropriate policy response 


\section{Spillover assessment framework}

Exposure to global shocks is an important impediment to sustained growth and development. Oil dependent economies are particularly vulnerable to macroeconomic volatility, sharp swings in term of trade, and variable external financing flows that amplify the impact of external shocks. Therefore, an illustration of assessment framework is presented in the next diagram, followed by a description of the framework component and underlying vulnerability to global financial shocks. In addition, outlines priority areas for further development of the analytical framework.

\section{Global Market Turbulence}

- Saudi Arabia, as a major oil producing country, is affected by global turbulence through trade and global financial risks. The reduction in trade financing usually aggravated the slowdown in global trade, particularly affecting emerging economies. Uncertainty about the scale of the downturn and continued stress on the financial system further increases Credit risks which arise because bank's assets quality declines as exports fall, corporate default rises, and households find it more difficult to service their debt, Monetary and financial system risks reflect the prospect of global deleveraging and reduced appetite for cross-border financing as shown in figure (1) The global financial stability map presents IMF overall assessment of how changes in underlying conditions and risk factors bear on global financial stability in the period ahead. Nearly all the elements of the map point to a deterioration of financial stability, with Emerging Market Risks having deteriorated the most. The economic downturn is expected to result in a deteriorating Macroeconomic Risks.

Sources of global financial risks including:

- While spill over and vulnerability assessment for emerging markets, focus on capital account or systemic financial sector crises and growth recessions due to global recession, little attention was paid to sharp declines in government spending arising from external shocks, which can generate substantial welfare losses and social dislocation especially in rentier economies like the Saudi economy. 
- Falling activity. The financial crisis results in particular strains for firms that rely heavily on externally sourced working capital (hence the particularly large downturn in industrial production and international trade) as well as SMEs with fewer financing options.

- Falling Revenues. While the downturn is eroding revenues everywhere, it is having the largest impact where public funds benefited particularly from unsustainable asset booms through capital gains and tax revenues from the financial-sector have continued to deteriorate, despite global policy easing. Among advanced economies, the pace of tightening of credit standards has moderated, but rising non-performing loans and pressures to deliver have weakened monetary policy transmission, which is further constraining lending. Risk appetite diminished as confidence remains depressed and counterparty risks high, adding to the pressures to further unwind risk assets. Market and liquidity risks remain elevated, as interbank markets are still functioning only at very short maturities and government guarantees of bank debt have allowed some medium-term funding in 2010 and 2011. Concerns have also arisen about spillovers to Sovereigns funds, which is exacerbated by the risk of contingent claims from household, bank, and corporate distress ( Global Financial stability Report).

- The global crisis triggers a steep fall in asset prices

- Rising home bias is a key risk for countries with major international financial exposures, either from large banking systems compared to their economies or from concentrated exposures to risky emerging markets.

Potentially costly bank recapitalization. The historical record suggests that the upfront cost of recapitalizing troubled banking systems is rarely below 10 percent of GDP, and that costs rise rapidly if decisive action is not taken early. Fiscal risks arising from recapitalization are notable for countries with large banking systems. Figure (1): Global Financial stability Map 


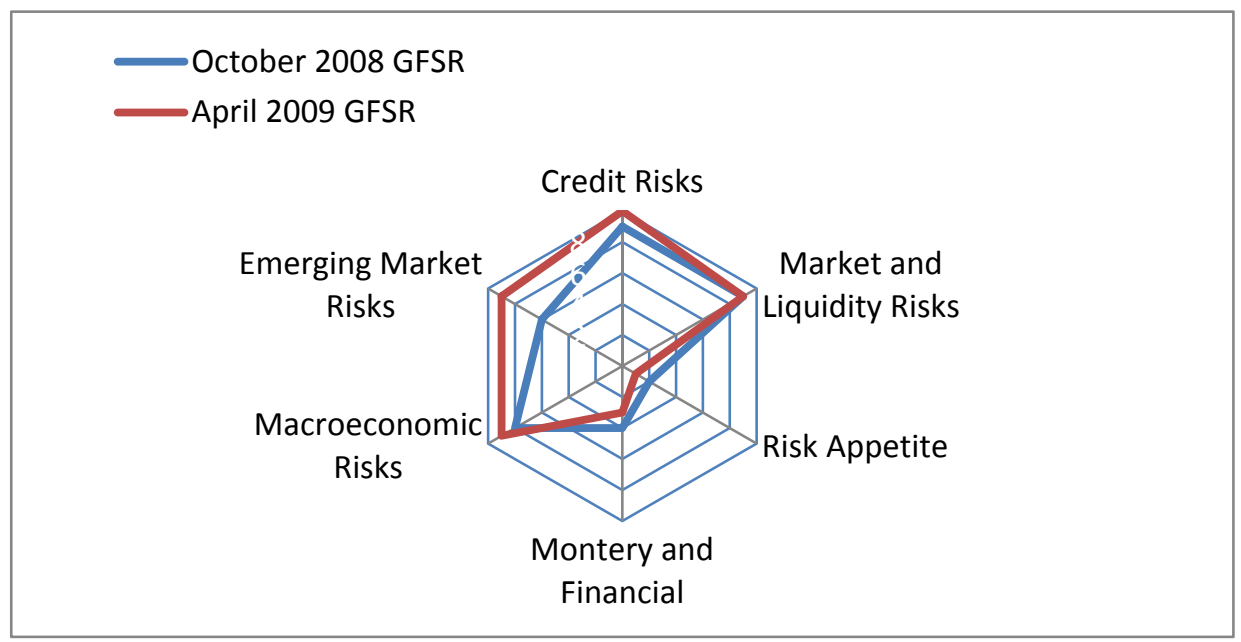

Source: GFSR, 2009, IMF

However, rising home bias might not be a potential risk to the Saudi economy because the country does not have major international financial exposure because according to SAMA reports the ratio of foreign assets to total assets of commercial banks in Saudi Arabia is only 11 percent. Despite its large banking system, Saudi banks source most of their funds locally and invest mostly domestically with $88 \%$ of their banking assets invested domestically, which provide a cushion to an extent from the global crisis. Saudi Arabia as a Country does not display financing needs but the private sector found, and will possibly find it more difficult to borrow from international investors to satisfy their financing needs. In addition, Saudi banks have limited direct exposure to real estate (Unlike UAE mortgage based real estate did not exist in Saudi Arabia and real estate finance has been driven by real estate development fund which is a government agency that provide free of interest loans,); therefore, potential loss from falling property prices is limited. However, the most direct effect of the crises on the Saudi Economy is falling activity. Firms financing needs are hampered by international finance strains as indicated by corporate performance after the crises hits as we will discussed later in the paper. 


\section{Overview the country Macroeconomic performance}

The Saudi economy economic performance in 2008 was very strong despite global turbulence, with real GDP growth estimated at about 4.2 percent. Following a decline in growth in 2009. The strength in the oil sector performance contributed to the high growth rate and a fiscal surplus of 32.5 in 2008 - as shown in table (1)- but activities weakened significantly in 2009 and the fiscal surplus came down to (-6.1). The economy has recovered in 2010 and early 2011 along with the rebound in global demand and oil prices. Overall real GDP growth rose from 0.1 percent in 2009 to 4.1 percent in 2010, driven by a rebound in oil sector GDP growth as well as acceleration in non-oil GDP growth from 3.5 percent to 4.9 percent with strong support from public spending. Profitability of corporates listed on the stock exchange also improved significantly in 2010 - net profits were 56 percent higher than in 2009. Available leading indicators - point of sale transactions, real credit, and business confidence surveys - all suggest a further strengthening of activity in the first quarter of 2011, with oil production now also increasing to compensate for lower output from Libya (IMF Country Report No. 11/292.September 2011).

Another macroeconomic indicator is inflation level, which slowed down from 9.9 in 2008 to 4.2 in 2009 due to the decrease in oil prices and the subsequent fall in government spending. However, inflation rose in 2010 driven by higher food prices and slowed back in 2011. As a major food importer, SA inflation rate reflect world commodity prices, fiscal spending, which both deriven by external global conditions and increasing rental prices, are an internal constraints the country face with the growing population and limited housing uintes. The country fiscal stand was supported by the increase in oil prices, therfore oil revenue compensated for the rise import prices. In conclusion, The spill over of global crisis has many venues through which it can be transmitted to the saudi economy, however, the unexpected increase in oil prices and the need to increase oil production played a cretical role on off sitting such negative effect. 
Table (1). Saudi Arabia Selected Macroeconomic indicators.

\begin{tabular}{|l|c|c|c|c|}
\hline & 2008 & 2009 & 2010 & 2011 \\
\hline Real GDP & 4.2 & 0.1 & 4.1 & 6.5 \\
\hline Oil & 4.2 & -7.8 & 2.2 & 9.4 \\
\hline Non-Oil & 4.3 & 3.5 & 4.9 & 5.4 \\
\hline Inflation & 9.9 & 4.2 & 5.4 & 4.6 \\
\hline Fiscal balance/GDP & 32.5 & -6.1 & 5.2 & 9.3 \\
\hline Current account/GDP & 27.8 & 5.6 & 14.9 & 20.1 \\
\hline WEO & 97 & 59.2 & 79 & 107.2 \\
\hline GDP (Billion/Saudi Riyals) & 1,788 & 1,413 & 1,680 & 2,147 \\
\hline
\end{tabular}

Source: IMF Country Report No. 11/292. September 2011, WEO, 2011.

\section{Financial Sector Vulnerability}

The recent global economic crisis revealed important warning signals about systematic risks and economic vulnerability. Financial sectors across the world face the risk of deleveraging because of the global financial crisis. Both borrowers and lenders are reluctant and discouraged to be committed under the current circumstances. The relevancy of this crisis for the Saudi financial sector as well as the rest of the GCC countries is that the banking sector constitutes a significant portion of market capitalization. Which in turn, largely determined by level of liquidity driven by oil prices. To investigate the crisis-finance relationship, we will look at the following indicators including (Global Financial Stability Report ). The size of the financial sector as measured by broad money in percent of GDP, Cross border Activities as measured by Net Foreign Assets in percent of GDP, Assets Intermediation as measured by claim on private sector in percent of GDP, and finally Capital Market Representation as measured by Market Capitalization in percent of GDP. Stock Market Performance and non-Performing Loans The Size of the Financial sector as measured by broad money in percent of GDP was at an average of 52\% until 2008 , the growth in broad money was a result of high liquidity mainly from current account surplus . 2009 level of the broad money was estimated at $62 \%$ of GDP despite the decline in oil prices due to the contraction in GDP. Saudi Arabia did not to have negative growth in money supply due to the limited presence of foreign banks and the limited level of expatriate share in deposit profile. Therefore, the size of the financial sector was determined solely by oil driven liquidity. The Saudi financial sector is relatively shielded from foreign depositors influence, but vulnerable to fluctuating oil prices. 
Table (2). The Size of the Saudi Financial Sector.

\begin{tabular}{|l|c|c|c|c|c|c|c|}
\hline & 2003 & 2004 & 2005 & 2006 & 2007 & 2008 & 2009 \\
\hline M3 & 111.32 & 132.29 & 147 & 176 & 210 & 247 & 252 \\
\hline M3/GDP & 52 & 53 & 47 & 49 & 55 & 51.5 & 72 \\
\hline
\end{tabular}

Source: SAMA Quarterly Statistical Bullitin, 2009

Cross border Activities as measured by Net Foreign Assets in percent of GDP. It provides indicator of the relative level of assets that are held outside the home country. The Saudi outward assets grew at an average of $35 \%$ of GDP up to 2004. However, in 2005 the size of assets held outside the country reached 50\% of GDP. And in 2008 Saudi Arabia net foreign assets was almost 91\% (Global Financial Stability Report) of the size of its GDP and expected to display slightly higher percentage in 2009 because of GDP contraction since the actual amount of foreign assets is expected to fall by almost $16 \%$ coinciding with the expected fall in oil prices and financial accumulation. Therefore, the high level of cross border activities for Saudi Arabia is one of the venues through which global economic crisis has direct negative impact.

Stock Market Performance reflected global crisis affect on asset prices and domestic liquidity. Equity markets were sharply down, losing half their value ( $\$ 270$ billion) in 2008 which present (-56 percent ) loses of market value from 2007 level The Recent swings in equity prices might be more pronounced than in past business cycles. The fall in revenues could come through several channels, including declines in capital gains taxation, a fall in wealth, consumption, and consumption tax revenue, and the impact on profit tax revenues from firms with trading activity. IMF estimates suggest that a 10 percent decline in equity prices leads cyclically adjusted revenues to fall by 0.07 and 0.08 percent of GDP in the current and subsequent years.

Table (3). Saudi Arabia Net Foreign assets.

\begin{tabular}{|l|c|c|c|c|c|c|c|}
\hline & 2003 & 2004 & 2005 & 2006 & 2007 & 2008 & 2009 \\
\hline NFA & 70 & 90 & 150 & 230 & 300 & 440 & 370 \\
\hline NFA/GDP & $\mathbf{3 3}$ & $\mathbf{4 0}$ & $\mathbf{5 0}$ & $\mathbf{6 7}$ & $\mathbf{8 2}$ & $\mathbf{9 1}$ & $\mathbf{9 2}$ \\
\hline
\end{tabular}

Source: SAMA Quarterly Statistical Bulletin 2009. 
Financial Sector Deleveraging: credit to the private sector as percent of GDP indicates the extent of credit booms due to leverage in the private sector. The leverage level in Saudi Arabia increased from 24\% of GDP in 2000 to $33 \%$ in 2004 then spiked up to $42 \%$ in 2008. However, one would expect that as global recession materialized, institutional deleverging materialize as well. Saudi banks' balance sheets expanded despite global recession because of central bank operations such as increasing direct bank deposits and increasing credits that reflects increased liquidity. Domestic liabilities are therefore comfortably replacing foreign banks liabilities. Overall financial soundness indicators and bank's balance sheets in Saudi Arabia. It points out to a strong capacity to cushion the economy from an immediate financial shock following the global trend as depicted in table (4). According to IMF (Hassa n, M., Parasad A., Williams, O., and Da Silva, A,, 2009) banks are profitable, well capitalized and have low non- performing loans. In comparison to the rest of the GCC countries as well as other emerging Markets, Saudi Arabia has very sound financial indicators, banks investment portfolios are relatively small, and mainly consist of the following:

Table (4). banks investment portfolios cross GCC countries and Emerging Market Average.

\begin{tabular}{|l|c|c|c|c|c|c|c|}
\hline & SA & Bahrain & Kuwait & Oman & UAE & Qatar & $\begin{array}{c}\text { Emerging } \\
\text { Markets }\end{array}$ \\
\hline NPL & 1.4 & 3.0 & 3.1 & 3.2 & 2.5 & 1.0 & 5.1 \\
\hline Capital Adequacy & 16.0 & 17.0 & 16.0 & 15.9 & 13.3 & 17.0 & 15.6 \\
\hline Capital Assets & 10.1 & 11.6 & 11.3 & 14.1 & 0.2 & 11.1 & 10.6 \\
\hline Provision Rate & 153.0 & 83.0 & 84.7 & 107.6 & 101.5 & 91.0 & 94.8 \\
\hline Return to Assets & 2.3 & 1.1 & 3.2 & 2.1 & 2.3 & 2.4 & 1.8 \\
\hline Return to Equity & 35.1 & 9.5 & 27.8 & 14.7 & 21.1 & 21.7 & 17.3 \\
\hline
\end{tabular}

Source: IMF Global Financial Stability Report 2009. 


\section{Corporate Sector Performance and Potential Vulnerabilities:} According to the IMF analysis of the global financial crisis impact of Saudi corporate sector performance, the crises have had an adverse impact on that sector during 2008. The financial performance of 27 corporate in the petrochemicals, investments and real estate sectors, constituting the majority of non-oil GDP in terms of assets was evaluated. Despite the fact that leverage is not projected and the sector isn't vulnerable, the corporate sector recorded lower asset growth and profitability. Which is reflected in table (5) as return to assets fell from $10.9 \%$ in 2006 to $8.9 \%$ in 2007 to $6.5 \%$ in 2008 .

The corporate sector has been affected by:

1. Global recession.

2. Falling value of investments in the financial sector, including real estate prices.

\section{Credit crunch}

Cross industry reduction in demand for goods and services. If these conditions persist, they can impair the asset quality of the banking system.

Table (5). Saudi Arabia Nonfinancial Corporate assets.

\begin{tabular}{|l|c|c|c|c|c|c|c|c|c|c|}
\hline \multirow{2}{*}{$\begin{array}{c}\text { Industry } \\
\end{array}$} & NO & \multicolumn{3}{c|}{$\begin{array}{c}\text { Assets } \\
\text { (USD Billion) }\end{array}$} & \multicolumn{4}{c|}{$\begin{array}{c}\text { Net Profit } \\
\text { (USD Billion) }\end{array}$} & $\begin{array}{c}\text { Return on } \\
\text { Assets } \\
\text { In Percent }\end{array}$ \\
\hline & & 2008 & 2007 & 2006 & 2008 & 2007 & 2006 & 2008 & 2007 & 2006 \\
\hline Petrochemicals & 13 & 116.6 & 98.3 & 58.4 & 7.6 & 8.8 & 6.3 & 6.5 & 8.9 & 10.9 \\
\hline Multi investments & 7 & 14.9 & 22.3 & 25.6 & -8.0 & 0.6 & 0.4 & 53.5 & 2.5 & 1.4 \\
\hline Real Estate & 7 & 13 & 10 & 5 & 0.7 & 0.8 & 0.1 & 5.5 & 7.3 & 2.2 \\
\hline Total & 27 & 144.7 & 131.1 & 89.4 & 0.4 & 10.1 & 6.8 & 0.2 & 7.7 & 7.6 \\
\hline
\end{tabular}

Source: Hassa n, M., Parasad A., Williams, O., and Da Silva, 2009.

Table (6). Saudi Nonfinancial Corporate Equity and debt.

\begin{tabular}{|l|c|c|c|c|c|c|c|c|c|c|}
\hline \multirow{1}{*}{ Industry } & NO & \multicolumn{3}{c|}{$\begin{array}{c}\text { Equity } \\
\text { (USD Billion) }\end{array}$} & \multicolumn{4}{c|}{$\begin{array}{c}\text { Total Debt } \\
\text { (USD Billion) }\end{array}$} & $\begin{array}{c}\text { Short-term } \\
\text { Debt Assets } \\
\text { (USD Billion) }\end{array}$ \\
\hline & & 2008 & 2007 & 2006 & 2008 & 2007 & 2006 & 2008 & 2007 & 2006 \\
\hline Petrochemicals & 13 & 44.2 & 37.8 & 28.2 & 55.6 & 43.7 & 20.9 & 11.1 & 10.8 & 7.9 \\
\hline $\begin{array}{l}\text { Multi } \\
\text { investments }\end{array}$ & 7 & 8.9 & 16.5 & 19.7 & 5.8 & 5.5 & 5.4 & 0.8 & 0.7 & 0.7 \\
\hline Real Estate & 7 & 9 & 7 & 5 & 3 & 2 & 0.3 & 1 & 1 & 0.3 \\
\hline Total & 27 & 61.3 & 61.2 & 52.3 & 64.0 & 51.4 & 26.68 & 13.0 & 12.1 & 8.9 \\
\hline
\end{tabular}

Source: Ibid 
Petrochemicals sector Despite the fact that the assets of this sector doubled between 2006 and 2008 reflecting expansion of investment in production capacities; The sector accounts for about 26 percent of market capitalization down from 32 percent in 2007-reversing first place with the banking sector. Although a trebling of debt financed the expansion, the debt equity ratio is still less than 1.5. The growth of net profits was much lower in 2008 (19 percent) as compared to 2007, reflecting both lower revenue and lower operating profits. The performance of this sector reflects the performance of the SABIC, the biggest listed firm in the Middle East and a world leader in the petrochemicals business. The net profits of SABIC in Q4 of 2008 showed a decline of 95 percent as compared to a year earlier. The sharp drop in the performance is attributed to the decline in demand for petrochemical products and metals because of the global recession as well as the credit crunch. Fertilizer prices have fallen by 70 percent since July 2008. The decline in demand for petrochemical products, particularly specialty plastics, arising from the crisis affecting the global automotive industry and building sectors has a strong impact on the overseas affiliates of SABIC and other petrochemical companies. Reflecting these developments SABIC recently laid off some workers at one of its Saudi plants in early 2009.

The major risk is that if credit becomes harder to obtain, costs will increase further and coupled with falling prices, would impose further strains on margins and postponement of new projects.

\section{Multi investment \& Real Estate Sector}

The real estate sector is small with an even smaller leverage. However, like other sectors, this sector has faced a decline in profitability in 2008. The outlook for real estate prices does not indicate well for this sector. If we look at external debt of the corporate sector total external debt of non banks in Saudi Arabia was $\$ 35$ billion, of which short-term debt falling due within one year is estimated at $\$ 14$ billion. As against this, non banks have cross border deposits of $\$ 52$ billion, which indicates that non banks (corporates) can comfortably service their external debt. 


\section{Saudi Arabia and possible transmission of Global Crisis}

Financial experts has been predicting that the global financial crisis have had limited direct impact so far on domestic financial markets in Saudi Arabia. Because banks are well capitalized and profitable and the exposure to international financial markets is limited. The majority of assets have been invested domestically, banks rely mainly on retail funding with domestic deposits representing about 85 percent of total liabilities of the banking sector, and capital flight from equity markets does not pose a major risk as foreign participation is low (about 2 percent of total investments). Also, the large stock of international reserves has been little affected by the crisis owing to SAMA's cautious investment strategy. Brad Setser and Rachel Ziemba (2009) also suggest that, unlike the other GCC countries, Saudi Arabia did not experience large losses on its foreign assets in 2008 because its portfolio was heavily concentrated in both U.S. dollar-denominated assets and fixed income securities. S.A is not an aggressive borrower so it doesn't have problems with rolling debt and it has not invested its wealth aggressively. Against this background Systemic risks remain high, despite policy actions, and some limited improvement in market functioning have yet to arrest the adverse feedback loop between the financial system and the real economy. The risks stem from the direct effect of falling oil prices and the indirect effect of global crises through many possible channels, including fiscal deficit; Tighter liquidity and SWF losses: poor returns, investment losses (Ralph Chami, 2009). Financial sector and fiscal vulnerabilities are closely intertwined. lack of credit and rising insolvencies tend to deepen the recession as the interaction between balance sheet weaknesses and economic activity gets stronger. At the same time, the cost of shortcircuiting this vicious macro-financial cycle through bank recapitalization and budget stimulus is raising questions about fiscal solvency in some cases. However, history shows that fiscal costs rise even further if financial problems are allowed to fester as the IMF (WEO 2009) suggested. An overview of the Saudi Arabia fiscal stands, liquidity level, and SWF performance is discussed next in order to assess the spillovers of global crises and assess the soundness of the system in downturn or in good times. 
What global recession mean for oil demand and for the Saudi Economy.One of the direct effect of global recession on the Saudi economy, as well as the rest major oil exporters, is the drop in world oil demand. According to Deutache bank global researsh, world oil demand grows at about $2 \%$ less than global GDP. Therefore If global GDP is down by $2 \%$ in 2009 , oil demand was expected to fall by $4 \%$ (Adam Sieminski,2009). In fact oil prices fell from its prices in 2008 by almost $63 \%$ consequently saudi arabi GDP fell by about 26\%. However, contradecting to all the speculation of further decrease in oil prices due to the slowens in gliobal GDP, oil price increaseg in 2010 back to its 2008 level and further incresed in 2010 by almost 27\% reaching USD 107. Therfore the optimistic scenario of stong spill over effect to Saudi Arabia through oil market was off set by the increase in prices and increase demand for saudi oil to compensate for lower libyan producation.

The budget and current account "break even price" has gradually increased for GCC countries as budget spending and investment have increased in recent years but If the price of oil remains low for a sustained period of time (e.g. below $\$ 40$ per barrel) Saudi Arabia could experience fiscal deficits in the future as shown in the next figure. And possible need to cancel or postpone some planned domestic investment projects. Saudi Arabia has cancelled a total of USD 14.7 Bn worth of oil $\&$ Gas and Petrochemicals projects mainly due to cost escalations and liquidity issues.

If oil prices were to remain low $(\$ 40-\$ 60)$, this would constrain government spending, including capital expenditure, and more importantly effect investor's confidence given the role of fiscal spending in stimulating private sector activities. Lower investment confidence would weaken private sector activities and eventually affect bank's asset quality. The economy remained highly dependant on oil revenue. Therefore the banking sector is expected outcome to experience high set back similar to the 1980 s crisis or even more because in 1980 change in real oil prices was(-24.\%) compared to (-54\%) in 2008 (Hasan, Parasad, Williams, and Da Silva,2009). Therefore, low oil prices would translate into lower government spending, the fiscal spending contraction is expected to trickle down to investment confidence. And government response would be either to cut capital spending to maintain fiscal and external balance which has adverse effect on the private sector activities 
or use SAMA's net foreign assets to compensate for large deficits . using NFA to finance budget deficit would erode the accumulated net foreign assets (2003-2008). In fact with the government generous fiscal spending in response to the political changes across the region, the break-even oil price for 2011 is $\$ 80$ and production is no less than $9.3 \mathrm{mbd}$ (IMF, Saudi Arabia Article IV consultation, September 2011). A less level of production or lower prices will result in fiscal deficit. Luckily, prices reached more than USD 80 in 2011, however, vulnerability of the economy to global fluctuation remain high and need to be addressed systematically through better management of oil revenues.

Tighter Liquidity has an immediate effect on corporate sector's performance. As data indicated, there has been very limited new credit extension across GCC countries including Saudi Arabia since the global financial turbulence started in September 2008. Despite the fact that private credit stock in Saudi Arabia is considerably high about $42.2 \%$ of GDP but a better indicator of credit tightness is the growth in the flow of credit rather than the stock of credit. Saudi Arabia experienced the sharpest pullback in credit out of all GCC While net new credit across GCC dropped to one third since the global crisis, it dropped by almost 2.5 in Saudi Arabia. Saudi Arabia records the slowest rate of credit growth in the area at 7.7\%, YoY as of May 2009 with all other GCC countries remaining in double digits figures (Net new credit in Saudi Arabia dropped by almost $88 \%$ between Sep 08-May 09). Despite the fiscal stimulus, the governments of the region are offering since the crisis, credit crunch has an immediate effect of the corporate sector ability to faucet liquidity outside Saudi Arabia through bonds, Sukuks and syndicated loans. While the stimulus money could provide banks with the recourses needed to compensate for decline in foreign sources of funds, global outlook and risk management constraints could limit the banks' willingness or may be ability to extend credit (Hassa, Parasad, Williams, and Da Silva. 2009). An expected outcome, might be an increase in corporate rollover risk and funding costs, which will weaken corporate profitability and liquidity and further reduce investment demand. Corporate sector has already shown signs of financial stress. As confirmed by a recent IMF report, the corporate sector in Saudi Arabia has been affected by (1) the global recession and cross-industry reduction in demand for goods and services; (2) the falling value of investments in the financial sector, including real estate prices; and (3) the credit 
tightening. As a result, corporate net profits declined by $65 \%$ in 2008 relative to 2007 and the return on assets is lower. This immediate negative effect of global crisis on the corporate sector indicates that if the financial crisis prolonged, the corporate sector's capacity could be severely hampered.

Sovereign Wealth Fund performance is one of the leading indicators of spill over effects. To an extent, it is one of the many channels through which global financial shock can be transmitted. Most GCC countries were hard hit by the present global turmoil. However, In contrast to many of its Gulf neighbors, Saudi Arabia's foreign asset stocks performed well considerably and was less effected the global economic turmoil, Ziemba and Setser (2009) concluded that SAMA assets actually increased by $30 \%$ in 2008 (table 7). This reflects the fact that the Saudi central bank, (SAMA), who is in charge of investing the country's surplus revenue abroad, has been more cautious comparing to its neighboring countries. Setser and Ziemba argued that SAMS conservative policy is reflected by its portfolio, where about $80 \%$ of the bank's portfolio consists of government bonds (mostly US dollar), rather than more risky equities. Nevertheless, this does not mean that Saudi Arabia's foreign asset stocks have remained immune from the crunch. SAMA data indicate that the rate of accumulation of foreign securities by the central bank slowed in the second half of 2008, as oil prices began to fall back.

Table (7): GCC Countries SWF Performance 2007, 2008.

\begin{tabular}{|l|c|c|c|}
\hline & 2007 & 2008 & $\%$ change \\
\hline Abu Dhabi Investment Authority & 453 & 328 & $-27.6 \%$ \\
\hline Kuwait Investment Authority & 262 & 228 & $-13.0 \%$ \\
\hline Qatar Investment Authority & 65 & 58 & $-10.8 \%$ \\
\hline SAMA & 385 & 501 & $30.1 \%$ \\
\hline Other GCC countries Central Banks & 116 & 84 & $-27.6 \%$ \\
\hline Total & 1281 & 1199 & $-6.4 \%$ \\
\hline Source: Setser ,Brad and Rachel Ziemba 2009.
\end{tabular}

The financial and economic crisis is affecting the fiscal accounts of virtually all countries including Saudi Arabia where discretionary stimulus has been used to support aggregate demand. According to IMF staff estimates, a discretionary fiscal impulse of 2.4 percent of GDP was 
undertaken in 2008, while crisis-related discretionary measures of 3.3 percent of GDP and 3.5 percent of GDP was implemented in 2009 and 2010 , respectively

- In sum global crisis is transmitted through Four effects are worth considering more closely (Severe disruptions in payment and credit markets could also abnormally reduce revenue collection, including through failure to file returns, under declaration, or payment deferrals. These effects, which may only affect the fiscal balance on a cash (and not accrual) basis, are difficult to estimate, and are not included here) as have been discussed: Equity prices. As discussed earlier that a 10 percent decline in equity prices leads cyclically adjusted revenues to fall by 0.07 and 0.08 percent of GDP in the current and subsequent years. Housing prices. IMF Staff regression estimates suggest that a 10 percent decline in real housing prices leads to a 0.27 percent of GDP decline in cyclically adjusted revenues in the following year, a stronger elasticity than for equity price changes (see also Carroll, Otsuka, and Slacalek, 2006; and Morris and Schuknecht, 2007). However, as the decline in housing prices has been smaller than for equity prices (less than 10 percent versus 50 percent), the fall in cyclically adjusted revenues arising from house price declines would be more contained ( 0.2 percent of GDP for the G-20 weighted average in 2009).

- Financial sector profits. In many countries, financial sector profits are an important source of corporate income tax (CIT) revenue; in some, stamp duties and financial transaction taxes are also levied. Over onequarter of CIT revenues for the United States and the United Kingdom during 2000-07 came from the financial sector. Extrapolating from this, the decline in financial sector profits could contribute to a 0.2 percent of GDP additional revenue decline (evenly split between 2008 and 2009) (CIT revenues averaged 3 percent of GDP across the G-20 during 2004-06 (weighted average). The calculation assumes that the financial sector pays 25 percent of CIT and has a decline in profits of 50 percent on top of the average decline in profits (already captured by the cyclical adjustment calculation). Because of the possible double-counting between this effect and the equity price effect, the former is reduced by a quarter). 
Commodity prices. The effect on fiscal revenues of the decline in commodity prices could be sizable in 2009 for some emerging markets Table (8). For the G-20 group, the figures are smaller, but significant ( 0.7 percent of GDP in 2009), largely reflecting the impact on Russia, Saudi Arabia, and Brazil (Another major G-20 oil producer, Mexico, hedged its 2009 oil export price at US\$70 per barrel. Staff estimate that each 10 percent fall in commodity prices will reduce G-20 fiscal revenue by 0.15 percent of GDP). Some countries could benefit to the extent that governments decide not to pass through to users the decline in commodity prices. This decision-effectively a cut in subsidies or a tax increase - is considered a discretionary change, and associated fiscal savings are not included in these adjustments.

Table (8). Loss of Fiscal Revenue Due to Commodity Price Movements In \% GDP

\begin{tabular}{|l|c|c|}
\hline & 2008 & 2009 \\
\hline Argentina & $\mathbf{0 . 0}$ & -0.4 \\
\hline Australia & 0.0 & -0.4 \\
\hline Brazil & 1.0 & -2.8 \\
\hline Canada & 0.3 & -0.7 \\
\hline Indonesia & 0.0 & 0.2 \\
\hline Mexico & 0.8 & -0.8 \\
\hline Russia & 1.7 & -5.9 \\
\hline Saudi Arabia & 15.0 & -29.7 \\
\hline South Africa & 0.2 & -0.1 \\
\hline
\end{tabular}

Source: IMF staff estimates. Overall, these other nondiscretionary effects appear to be sizable as shown in Table (9). Their impact could account for an estimated 1.3 percent of GDP deterioration in fiscal positions of G-20 countries in 2009.

Table (9). G-20 Countries: Other Nondiscretionary Factors As \% GDP, relative to previous year.

\begin{tabular}{|l|c|c|c|c|c|c|}
\hline & & 2008 & & & 2009 & \\
\hline & $\begin{array}{c}\text { All } \\
\text { G-20 }\end{array}$ & Advanced & Emerging & $\begin{array}{c}\text { All } \\
\text { G-20 }\end{array}$ & Advanced & Emerging \\
\hline $\begin{array}{l}\text { Nondiscretionary } \\
\text { Factors }\end{array}$ & 0.1 & -0.4 & 1.0 & -1.3 & -0.5 & -2.4 \\
\hline Equity Prices & -0.2 & -0.3 & 0.0 & -0.5 & -0.4 & -0.5 \\
\hline Housing Prices & 0.1 & -0.1 & 0.3 & -0.2 & -0.3 & 0.0 \\
\hline Financial Sector & -0.1 & -0.1 & -0.2 & -0.1 & -0.1 & -0.2 \\
\hline Interest Payment & 0.0 & 0.0 & 0.1 & 0.2 & 0.4 & 0.0 \\
\hline Commodity Prices & 0.3 & 0.0 & 0.8 & -0.7 & 0.0 & -1.8 \\
\hline
\end{tabular}

Sources: IMF, World Economic Outlook, April 2009; Bloomberg and other financial source. 


\section{Conclusion}

Saudi Arabia is confronting the current global crisis from a position of strength, as a track- record of sound macroeconomic policy implementation provides the government with considerable advantage, particularly on fiscal policy.

\section{The global financial crisis has had limited direct impact so far on} domestic financial markets but the global slowdown has begun to affect the real economy. Banks are well capitalized and profitable (although profits declined slightly in 2008 and in 2009) and the exposure to international financial markets was limited. The majority of assets have been invested domestically, banks rely mainly on retail funding with domestic deposits representing about 85 percent of total liabilities of the banking sector, and capital flight from equity markets does not pose a major risk as foreign participation, is low (about 2 percent of total investments). The large stock of international reserves has been little affected by the crisis owing to SAMA's prudent investment strategy. To ease a tight liquidity situation, the authorities cut policy rates, lowered reserve requirements, guaranteed deposits, and placed deposits in banks. However, weaker investor sentiment weighed on equity markets, which declined sharply in late 2008 through 2010 (by 44 percent since the beginning of the crisis 2008). The slowness of the truckle down effect of the global crisis to the Saudi market is a direct result of high level of oil prices partly due to the political turmoil in the region. However, the country was and still are effected through trade, reflected in high inflation rate, tighter liquidity and weak investor confidence. Government generous spending has been successful in reducing the impact of the global crisis, but Saudi Arabia should not count on that policy because of the volatile nature of oil market and global demand. In light of anticipated fall in oil prices, the current strategy is not sustainable. Only through capital market deepening to provide stable long-term financing for companies and states alike. Fiscal stimulus packages should consist, as much as possible, of temporary measures; Policies should be cast within medium-term fiscal frameworks that envisage a gradual fiscal correction, once economic conditions improve, with proper arrangements to monitor progress; Governments should pursue growth enhancing structural reforms. 


\section{References}

[1] Arora, Viver, and Martin Cerisole (2000) How Does U.S. Monetary Policy Influence Economic Conditions in Emerging Markets. IMF WP 00/148.

[2] Arora, Viver and Athonasios Vamvadikis (2005) How Much Do Trading Partners Matter for Economic Growth?", IMF Staff Papers, 52(1).

[3] Arora, Viver and Athonasios Vamvadikis (2004) The Impact of U.S. Economic Growth on the Rest of the World: How Much Does It Matter? Journal of Economic Integration, 19(1), March 2004, 1-18.

[4] Bayoumi, Tamim and Andrew Swiston (2007A) Foreign Entanglements: Estimating the Source and Size of Spillovers Across Industrial Countries. IMF Working Paper Series, WP/07/182.

[5] Bayoumi, Tamim and Andrew Swiston (2007B) The Ties that Bind: Measuring International Bond Spillovers Using Inflation-Indexed Bond Yields," IMF Working Paper Series, WP/07/128.

[6] Carroll, Christopher D., Misuzu Otsuka and Jiri Slacalek (2006) How Large Is the Housing Wealth Effect? A New Approach. working paper 12746, NBER.

[7] Chami, Ralph (2009) The Financial Crisis: Relevance and Implications for GCC countries. IMF Institute, presented at the Institute of Diplomatic Studied, Riyadh, Saudi Arabia.

[8] Chan-Lau, Jorge., Srobona Mitra, and Li Lian Ong (2007) Contagion Risk in the International Banking System and Implications for London as a Global Financial Center, IMF Working Paper Series, WP/07/74.

[9] Cerisola, Martin, Geoffrey Bannister, Gaston Gelos and Fabian Valencia (2008) A survey of Financial Linkages" chapter 12 in "Who is driving Whom: Analyzing External and Intra-Regional Linkages in America. IMF, p. 165.

[10] Cihák Martin and Li Lian Ong ( 2007) Estimating Spillover Risk Among Large EU Banks. IMF Working Paper Series, WP/07/267.

[11] Dooley, Michael, Edurdo Fernandez-Arias and Kenneth Kletzer (1994) Is the Debt Crisis History? Recent Private Capital Inflows to Developing Countries. World Bank Policy Research WP No.1327.

[12] Duggar, Elena and Srobona Mitra ( 2007) External Linkages and Contagion Risk in Irish Banks," IMF Working Paper Series, WP/07/44.

[13] Deutshe Bank ( 2009) Special Publication "GCC Banks: Able but not Willing", London July/3.

[14] Eichengreen, Barry and Mody Ashoka (1998) What Explains Changing Spreads on Emerging Market Debt: Fundamentals or Market Sentiment. NBER Working Paper No. 6408.

[15] Gapen, Michael, Dale Gray, Cheng Hoon Lim and Yingbin Xiao (2005) Measuring and Analyzing Sovereign Risk with Contingent Claims. IMF $\mathrm{WP} / 05 / 155$.

[16] Hassan, Maher, Ananthakrishnan Prasad and Oral Williams and Arthur Da Silva (2009) The capacity of the Saudi Financial System to Withstand the Impact of the Global crisis. IMF, WP/09/162.

[17] Ilahi, Nadeem and Riham Shendy ( 2008) Do the Gulf Oil-Producing Countries Influence Regional Growth? The Impact of Financial and Remittance Flows. IMF Working Paper Series, WP/08/167. 
[18] International Monterey Fund (2008) Can Asia Decouple? Investigating Spillovers from the United States to Asia. Asia and Pacific Regional Economic Outlook, April, Chapter 2, pp. 21-41. (2008) Regional Economic Outlook.Transmissions of Global Shocks to LAC," world economic and Financial surveys, pp. 13-24.

[20] _ (2008) Who's Driving Whom? Analyzing External and IntraRegional Linkages in the Americas. editors Mühleisen, M. et. al.

[21] (2008) World Economic Outlook: Financial Stress, Downturns Recoveries, pp. 49-80. , (2009) Global Financial Stability Report :Responding to the Financial Crisis and Measuring Systemic Risks, pp. 73-111 . , (2009) The Implications of the Global Financial Crisis for LowIncome Countries. IMF Multimedia Services Division, Typesetting: Alicia Etchebarne-Bourdin. , (2009) World Economic Outlook: Vulnerability Exercise for Advanced Economies, pp. 76-96.

[25] , (2011) Country Report No. 11/292, World Economic Outlook.

[26] (2011) Saudi Arabia Article IV consultation, September 21.

[27] Kanda, Daniel ( 2008) Spillovers to Ireland. IMF Working Paper Series, WP/08/2.

[28] Klyuev, Vladimir (2008) Real Implications of Financial Linkages Between Canada and the United States. IMF Working Paper Series, WP/08/23.

[29] Morris, Richard and Ludger Schuknecht (2007) Structural Balances and Revenue Windfalls: The Role of Asset Prices Revisited. ECB Working Paper No. 737 (Frankfurt: European Central Bank).

[30] SAMA Quarterly Statistical Bullitin (2009).

[31] Setser, Brad and Rachel Ziemba (2009) GCC Sovereign Funds: Reversal of Fortune.” Council on Foreign Relations, Center for Geoeconomics Studies, (New York, USA). http://www.cfr.org/economics/gcc-sovereign-funds-reversal-fortune/p18017

[32] Sieminski , Adam, E. (2009) Global Oil and Gas Outlook. Deutsche Bank Global Research, April 23. 
امتذاد أثز الأزمة الاقتصادية العالمية إلى الاقتصاد السعودي

\author{
هند محمد آل الشيخ \\ قطاع المالية والاقتصادية، معهُ الإدارة العامة الفئ \\ sheikhhi@ipa.edu.sa \\ معارة لجامعه الملك عبداله للعلوم والثقنية \\ قسم التتمبة الاقتصادية، مستشارة سياسات واستراتبيجيات
}

Hend.alsheikh@kaust.edu.sa

المستخلص: تقدم هذه الورقة إطارا لتقبيم أثر الأزمة الاقتصادية

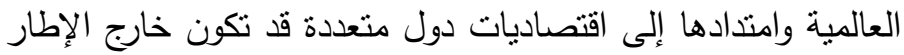

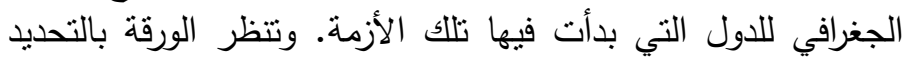

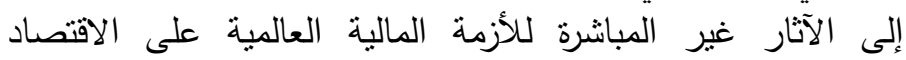

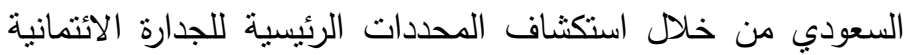

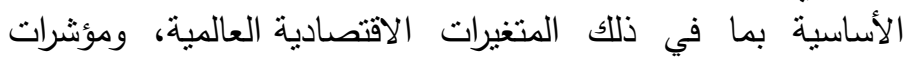

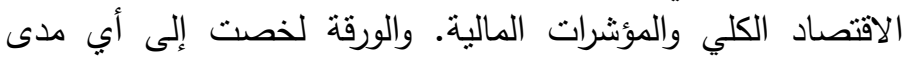

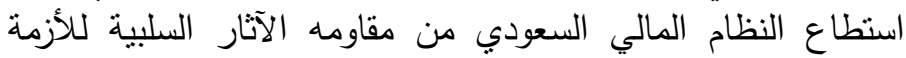

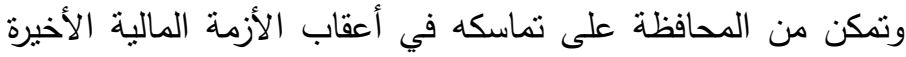

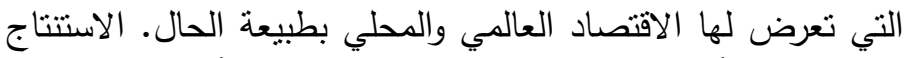

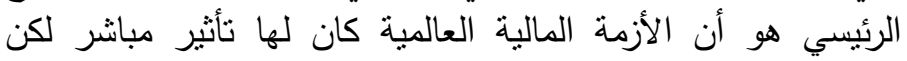

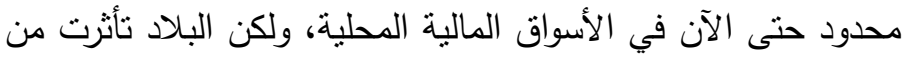

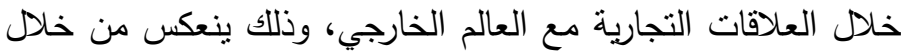

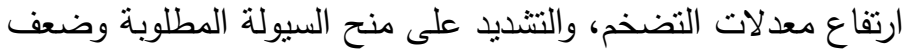

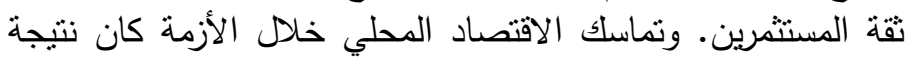

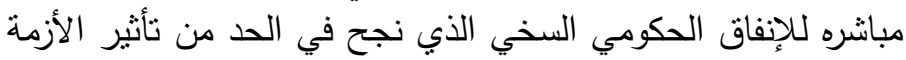

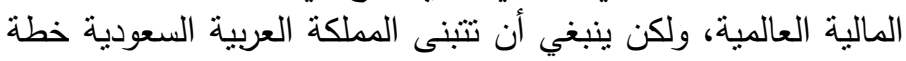

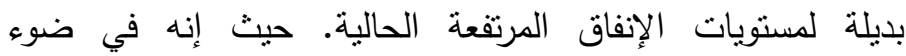

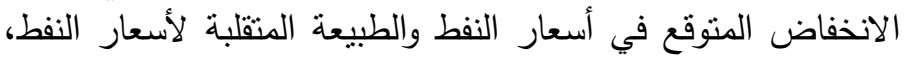

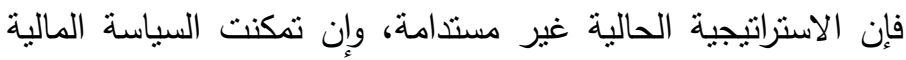

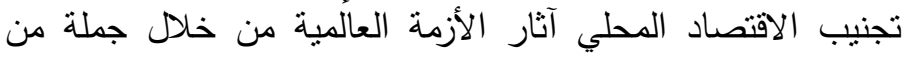

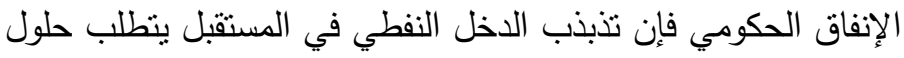
جذريه لمواجهات الأزمات العالمية. 